\author{
Astrīda Vucāne \\ Ventspils University College/Liepāja University, Latvia \\ e-mail: vucane.astrida@gmail.com
}

\title{
LATVIAN TERMINOLOGY OF MARRIAGE IN 20TH CENTURY LEGISLATIVE ACTS
}

\begin{abstract}
Among the political changes brought about by the First World War was the formation of new countries, including Latvia. This in turn resulted in a strong need for the first national legislative acts and thus a substantial amount of effort to develop Latvian legal terminology which dates back to the beginning of the 19th century.

The purpose of the paper is to study the development of Latvian terminology of marriage in the 20th century through analysis of the relevant body of laws. The paper focuses on marriage-related terms extracted from the major legislative acts governing the institution of marriage in the 20th century. The present study adopts the qualitative research approach which constitutes data collection (selection of the relevant legislative acts, term extraction) and data analysis (qualitative analysis of extracted terms). For the purposes of a comprehensive and efficient analysis of the extracted legal terms, marriage terms are divided into the following five thematic groups: 1) engagement; 2) entering into marriage; 3) nullity of marriage; 4) dissolution of marriage (divorce); and 5) consequences of dissolution or nullity of marriage. The paper suggests that the core of the Latvian terminology of marriage has remained stable, as entering into marriage is a solid procedure where two interested parties give notice to a public or religious institution in order to officially register their relationship. Similarly, both parties often feel the need to terminate this relationship just as officially. This stability of fundamental processes contributes to terminological continuity.

Keywords: civil law, divorce, family law, history of legal language, legal terms, marriage.
\end{abstract}

\section{Introduction}

After the First World War the world political map considerably changed, as empires broke up and new countries were formed, including Latvia. This resulted in a strong need for the first national legislative acts and consequently a substantial amount of effort to develop Latvian legal terminology which dates back to the beginning of the 19th century. The first 
translations of legal texts into the Latvian language, however, appeared already in the 17th century, yet more serious and purposeful work was carried out in the second part of the 19th century (Štekerhofa, 2016).

The aim of this paper is to study the development of Latvian terminology of marriage in the 20th century through analysis of the relevant body of laws. The study focuses on the marriage-related terms extracted from the major legislative acts governing the institution of marriage in the 20th century. These include the Code of Laws on Documents of Civil Status and on Marriage, Family and Guardianship Law of the Latvian SSR (1919), the Marriage Law 1921, the Civil Law 1937, the Code of Laws on Marriage, Family, and Guardianship of the RSFSR (1940), the Marriage and Family Code of the Latvian SSR (1969), and the restored Civil Law of Latvia (1993). It should be noted that the study does not include the latest amendments made to the Civil Law over the last 15 years.

The present paper adopts the qualitative research approach which constitutes data collection (selection of the relevant legislative acts, term extraction), and data analysis (qualitative analysis of extracted terms).

\section{Legislative Acts Governing the Institution of Marriage}

Analysis of the extracted material often requires additional background information in order to make the analysis more efficient and comprehensive. Therefore the first chapter of the paper provides a brief description of all the six major legislative acts which form the basis of the present study, i. e. the Code of Laws on Documents of Civil Status and on Marriage, Family and Guardianship Law of the Latvian SSR (1919), the Marriage Law 1921, the Civil Law 1937, the Code of Laws on Marriage, Family, and Guardianship of the RSFSR (1940), the Marriage and Family Code of the Latvian SSR (1969), and the restored Civil Law of Latvia (1993).

At the beginning of the 20th century the territory of Latvia was part of the Russian Empire, and the entering into and dissolution of marriage were governed by the Digest of Laws of the Russian Empire (Свод законов Российской империи), Volume 10, which stipulated that marriage shall be entered into and dissolved according to the rules of a specific religious denomination. Since this body of law is in the Russian language, it does not constitute an object of this study.

Thus the first legislative act analysed in the paper is the Code of Laws on Documents of Civil Status and on Marriage, Family, and Guardianship 
Law of the Latvian SSR (Кодекс о законов об Актах гражданского состояния, Брачном, Семейном и Опекунском праве; Likuтu kodekss par civilstāvokla aktiem, laul̄̄bas, ǵimenes un aizbildnības tiesībām) which was introduced in 1919. This body of law was only applicable for approximately a year during the short-lived Latvian Socialist Soviet Republic (SSR) (1918-1920) which was formed during the Latvian War of Independence. It was published in two columns - the left one was written in Latvian, while the right one in Russian, and the Latvian text was obviously greatly influenced by the Russian text, as demonstrated by the sentence structure and choice of words. For instance, when stipulating that it is also allowed to register a marriage outside the specific premises, the Russian text reads that бракосочетание допускается which is literally translated into Latvian as laulību noslēgšana tiek pielaista (Section 54). The raising of objections to marriage is referred to as nротест против брака in Russian and protests pret laulības noslēgšanu in Latvian (Section 63), while false information is called ложные свидения in the Russian text and correspondingly melu zingas in the Latvian text (Section 64).

After the First World War a modern understanding of marriage as a civil agreement, which can be entered into and then terminated with the help of national authorities, was strengthened in Latvia (Lazdinsš, 2003). Therefore in 1921 the Marriage Law (Likums par laulību) was adopted in the newly formed Republic of Latvia, pursuant to which a marriage could be performed by a government official or a cleric and divorce cases were settled by courts. It was a very progressive law, since it stipulated the freedom of divorce at courts, as well as mutual rights and obligations of former spouses after dissolution of marriage.

Provisions of the Marriage Law were taken over by the Civil Law (Civillikums) which was adopted in 1937. Pursuant to the Civil Law, a statement that a marriage has broken down irretrievably was considered sufficient grounds for divorce, and this was a very progressive principle way ahead of time. For instance, in England and Wales, this principle was only introduced by the 1969 Divorce Reform Act, namely 30 years later.

After the occupation of Latvia in 1940 marriage law was first regulated by the Code of Laws on Marriage, Family, and Guardianship of the RSFSR (Кодекс законов о браке, семье и опеке РСФСР; KPFSR Laulïbas, gimenes un aizbildnības likumu kodekss). This Code of Laws of the Russian Soviet Federative Socialist Republic (RSFSR) was applied to Latvia from 1940 to 1969. Starting from 1969 marriage law was governed by the Marriage and Family Code of the Latvian SSR (Latvijas PSR laulības un gimenes kodekss) (1969-1992). Only marriages registered by the State Civil 
Registry Office were recognised by the state, which considerably narrowed the scope of marriage law, and some Latvian legal historians have even characterised this period as regression of marriage law (Lazdiņš, 2003).

After Latvia regained its independence the Civil Law 1937 was reinstated in 1992-1993. The reinstated Civil Law (Civillikums) is, in substance, the transfer of the Civil Law 1937. It perfectly embodies the principle that legal language is conservative and may contain words which have disappeared from ordinary language (Mattila, 2013).

\section{Comparative Analysis of Legal Terms}

In order to carry out a comprehensive analysis of the extracted legal terms and make it more efficient, marriage terms have been divided into the following five thematic groups: 1) engagement; 2) entering into marriage; 3) nullity of marriage; 4) dissolution of marriage (divorce); and 5) consequences of dissolution or nullity of marriage. The most illustrative examples for each group are discussed below by performing a comparative linguistic analysis.

According to the Latvian Dictionary of Legal Terms, engagement ( saderināšanass) is a clear mutual promise expressed in any form, whether in writing or orally, through actual actions to enter into marriage (JTV, 1998). A section which refers to engagement can only be found in the Civil Law 1937 and the current Civil Law, as Soviet law did not recognise the institution of engagement. Only slight terminological changes can be observed in this group, mostly referring to sexual morality. For instance, the current Civil Law no longer contains terms such as lustful affairs (miesīgi sakari) and to lead an indecent life (dzīvot piedauzīgi). The core has, however, remained intact, as the major terms, e.g. engagement (saderināšanās), fiancée, fiancé (saderinātais), mutual promise (savstarpējs solūjums), gift (dāvana) etc. have not been subject to any changes.

In order to enter into marriage, a person must be at a certain age. This requirement has been expressed differently over the time. The Code of Laws on Documents of Civil Status and on Marriage, Family, and Guardianship Law of the Latvian SSR (hereinafter - the Code of Laws 1919) and the Marriage and Family Code of the Latvian SSR (hereinafter - the Marriage and Family Code 1969) contain reference to the marriage age (laulizbas vecums), while the Marriage Law 1921 (Section 3) and the Civil Law 1937 (Section 33) stipulate that "marriage is not allowed for minors" (aizliegta laulība nepilngadīgiem) also specifying that men should reach the age of 18 
but women - the age of 16 (Section 2 and Section 32 respectively). Pursuant to Section 32 of the current Civil Law, marriage is not allowed before reaching the age of 18 (aizliegta laulība pirms astonpadsmit gadu vecuma sasniegšanas), and the Civil Law also contains the term adult (pilngadīga persona).

A section prohibiting marriage between legally incapable persons (rīcības nespējigas personas) has been deleted from the current Civil Law. Previously this requirement was expressed differently - in 1919, as a requirement to have a sound mind (büt pie pilna prāta), in 1921, marriage was not allowed for persons weak in mind (gara väjie), while in 1937, the weak in mind became sick in mind (garā slimie). In 1940, a marriage could not be registered between persons recognised as imbecile or weak in mind (plānprātīgs vai garā slims), but in 1969, between legally incapable persons due to mental illness or mental deficiency (rīcības nespèjīgs gara slimības vai plānprātības dēl). The reinstated Civil Law preserved the wording used in the Soviet Marriage and Family Code 1969, i.e. a legally incapable person due to mental illness or mental deficiency (rīcības nespējīgs gara slimības vai plānprātības dēl).

Concerns about public health and efforts to prevent sexually transmitted diseases resulted in a corresponding provision suggested by Dr. Gustavs Reinhards (1868-1937), an ophthalmologist and Member of the Parliament (Latvijas Vēstnesis 1920). Pursuant to Section 4 of the Marriage Law 1921 and Section 34 of the Civil Law 1937, marriage was also prohibited between persons who suffer from venereal diseases in contagious form (slimot ar veneriskām slimībām lipīgā stadijā).

All the relevant bodies of law explicitly prohibited bigamy, i.e. the act of entering into a marriage with a person while being legally married to another person. Although the term bigamy (bigämija) was used in the Latvian language at least since the 1860s, mainly referring to the fact of being married to two women, it has not been used in any of the specific legislative acts. The legislators have also avoided the term multi-marriage (daudzlaulība) which was formed in the Latvian language in the second part of the 19th century (Birzina, 1991). Instead, a descriptive approach has been applied in all cases. Section 68 of the Code of Laws 1919 stipulated that persons may not enter into a marriage if they have already entered into a registered marriage or a marriage equivalent to a registered marriage (laulība nevar iestāties personas, kuras jau atrodas reǵistrētā vai reǵistrētāi pielīdzinātā laulīb $\bar{a}$ ). Pursuant to Section 7 of the Marriage Law 1921 and Section 38 of the Civil Law 1937, a person who has already entered into a marriage may not enter into a new marriage. The Code of Laws 1940 contained 
a provision that marriages may not be registered between persons, out of which one or both persons have already entered into another registered or non-registered marriage (Section 6). Section 16 of the Marriage and Family Code 1969 in turn stated that a marriage may not be registered between persons, out of which one or both persons have already entered into another marriage.

Prior to entering into marriage, a procedure called proclamation (izsludināšana) takes place. It is public, official announcement of an impending marriage by a register office or according to the rules of the relevant religious denomination. The purpose of proclamation is to enable anyone to raise any legal impediments to the marriage in order to prevent marriages that are invalid. This term might seem obsolete, but up to 1 January 2013 it could still be found in the Civil Law. The Code of Laws 1919 required the announcement of marriage, and so did the Marriage Law 1921 and the Civil Law 1937. The Marriage and Family Code 1969 in turn did not contain such a term, instead it established a requirement for submission of an application (iesniegt pieteikumu) one month before the marriage, and during this period any affected person could raise their impediments. This proclamation is, in fact, the banns of marriage previously performed by a church. No matter how this procedure has been called over the time - banns of marriage, proclamation, or simply submission of an application, its nature and purpose has remained the same.

Under different powers a register office at which a notice of marriage is given has been named differently. The Code of Laws 1919 referred to it as a civil registry office (civilstāvokļa aktu reǵistrācijas nodala), the Civil Law 1937 - as a register office (dzimtsarakstu nodala), the Marriage and Family Code 1969 - as a state civil registry office (valsts civilstāvoklla aktu registrācijas iestāde) and now it is again a register office (dzimtsarakstu nodala). According to Birziņa the term dzimtsarakstu nodala was created by the Latvian lawyer and writer Andrejs Stêrste (1853-1921) who was actively engaged in translation of legal texts and development of Latvian legal terminology (Birziņa, 1991).

Nullity of marriage is a declaration that the relevant marriage is null and void and has never happened. The Code of Laws 1919 referred to this declaration as laulības nepilnspeccìba meaning that a marriage is not in full force. The opposite situation was laulības pilnspēcība which meant a marriage being in full force. In the Marriage Law 1921 laulības nepilnspēcība was changed to laulības neesamība that could be translated as non-existence (or nullity) of marriage. Yet the Marriage Law 1921 also kept the term laulības pilnspēcìba thus showing some inconsistency in the use of terms. 
The Civil Law 1937 only used the term non-existence (or nullity) of marriage (laulības neesamība) which has been preserved in the Civil Law today.

A marriage may be declared null and void on different grounds, such as invalid registration, non-compliance with the requirements for entering into a marriage (e.g. marriage age), forced marriage etc. One of the grounds for nullity of marriage is the fact that marriage has been entered into fictitiously, namely without the intent to create a family. The reinstated Civil Law does not contain a term marriage of convenience (also called sham or fake marriage - fiktivva laulība), and it has not been used in the first Civil Law. However, the Marriage and Family Code 1969 did include this term stipulating in its Section 44 that marriage may be declared invalid [...] if the marriage has been registered without the intent to create a family (fake marriage). This explains why this term is so well accepted and widely used in Latvia after restoration of independence.

The issue of marriage of convenience was recently raised at the European level through the project "Preventing Human Trafficking and Sham Marriages: A Multidisciplinary Solution" (HESTIA) that involved public and non-governmental organisations from six European Union countries. This project also touched on a number of terminological aspects, including the choice of the most appropriate terms in both English and Latvian. As a result of discussions and linguistic analysis the Latvian term fiktivva laulība proved to be the most reliable, corresponding and equivalent to the English term marriage of convenience (Vucāne 2015).

As to the dissolution of marriage or divorce, the most distinct differences may be observed between the old version and the new version of the Civil Law. For instance, a ripped apart marriage ( $i z \bar{a} r d \bar{\imath} t \bar{a}$ laulība) in the Civil Law 1937 has become a broken down marriage (izirusi laulība) in the reinstated Civil Law, the first being much more poetical than the second one. In this case a legal term is, in fact, a phrase which also forms part of ordinary language but has a special meaning in legal language (Mattila, 2013).

If the Civil Law 1937 (and also the Marriage Law 1921) stipulated that a spouse may request dissolution of a marriage, if the other spouse threatens his or her life or health, or beats or tortures him or her (laulätais var prasīt laulības šķiršanu, ja otrs laulātais apdraud viņa dzīvību vai veselību, vai sit vai spīdzina vinu, Section 43 and Section 70 respectively), the grounds for divorce referred to in the existing Civil Law is physical, sexual, psychological or economic violence (fiziska, seksuāla, psihologíska vai ekonomiska vardarbizba, Section 74). Thus this provision has become more sophisticated and complex involving more aspects and leaving space for wider interpretation. 
As the divorce procedure has become comparatively simple, a number of previous grounds for dissolution of marriage have been deleted in the new version of the Civil Law. For instance, grounds, such as adultery (laulības pārkāpums), which was indicated in Section 70 of the Civil Law 1937, physical inability to maintain conjugal life (fiziska nespēja piekopt laulības kopdzīvi) and infertility (neauglība), referred to in Section 47 of the Marriage Law 1921 and Section 75 of the Civil Law 1937, or disgust to conjugal life (riebums pret laulības kopdzīvi), specified in Section 48 of the Marriage Law 1921, may no longer be found in the reinstated Civil Law. It should also be noted that, except for the grounds disgust to conjugal life, all the other grounds referred to above were also included in the Legal Dictionary of 1942 and apparently treated as legal terms (JTV, 1942).

The Marriage Law 1921 contained the term marital separation (laulāto atšķiršana). Legal separation is a process by which a couple decides to live apart while still remaining officially married. While separation does not automatically lead to divorce, it is often the first step before dissolution of marriage. The Civil Law 1937 did not include this term, and the institution of separation was apparently not considered necessary when reinstating the Civil Law after Latvia regained its independence.

One of the most interesting examples in the group of terms related to the consequences of dissolution or nullity of marriage might be the term maiden name (pirmslaulības uzvārds) which, in fact, only appears in the relevant legislative acts starting from 1940. Before that, this concept was explained descriptively as surname used before marriage (uzvārds, $k \bar{a} d \bar{a}$ saucās pirms laulības, Section 102 of the Code of Laws 1919), or simply surname before marriage (uzvārds, kas bijis pirms laul̄̄bas, Section 59 of the Marriage Law 1921 and Section 80 of the Civil Law 1937).

Also the term married name (laulībā iegūtais uzvārds) has been subject to changes over the century. It has been referred to as common name (kopējs uzvārds), married name (laulības uzvārds) or united name (savienotais uzvārds, Section 100 of the Code of Laws 1919), surname of husband (vīra uzvārds, Section 59 of the Marriage Law 1921 and Section 80 of the Civil Law 1937) and name of spouses (laulāto uzvārds, Section 18 of the Marriage and Family Code 1969).

The best interests of a child were already being taken into account in 1921, as reflected by the Marriage Law 1921 through terms, such as wish of a child (bērna vēelēsanās), interests of a child (bêrna intereses), and the right to contact with a child (tiesība satikties ar bērnu) that are now simply covered by a single term access rights (saskarsmes tiesība, Section 77). 


\section{Conclusions}

Terminologically some parallels can be drawn between the Code of Laws 1919, the Code of Laws 1940, and the Marriage and Family Code 1969, as they all represent the Soviet understanding of family law. For instance, they all exclude the institution of engagement and consequently the relevant engagement terms. As the procedures for entering into marriage and dissolution of marriage are more or less the same, the specific bodies of law contain reference to the same authorities and required documents.

The Marriage Law 1921 was in turn incorporated in the Civil Law 1937 which is clearly reflected by the choice of marriage terms. Most of the terms used in the Marriage Law 1921 are the same as those which may be found in the Civil Law 1937. Terms, such as civil registry office (dzimtsarakstu nodala), surname of husband (vīra uzvārds) or ripped apart marriage ( $i z \bar{a} r d \bar{\imath} t \bar{a}$ laulība) have been transferred from the Marriage Law 1921 to the Civil Law 1937 without any changes.

As the Civil Law 1937 was reinstated after Latvia regained its independence, the core of the existing Civil Law terms has mostly remained intact, except for rather slight changes which have been made to adjust the terms to stylistic and grammatical standards, as well as spelling rules of the Latvian language today. It has been widely accepted that modernised legal terminology has the tendency to refer to ordinary language (Galdia, 2009); however, the reinstated Civil Law seems to preserve the spirit of the old Civil Law which is a good legacy in terms of both language and law.

The choice of the relevant terms related to marriage also reveals a couple of social aspects. For instance, the term surname of husband (vīra uzvārds) used in the bodies of law of the 1920s and 30s indirectly demonstrates the social status of women, as it is obviously assumed that a woman takes her husband's surname, instead of keeping her surname or the husband taking her surname. As a result of political correctness, insulting terms such as persons weak in mind (garā vājie), sick in mind (garā slimie), and imbecile ( $p l \bar{a} n p r a \bar{t} \bar{g} g s$ ), have disappeared from the legal texts.

When comparing legislative acts from the first half of the 20th century to those of the second half of the century, it is obvious that legal Latvian has lost some of its colour and expressiveness, becoming more formal and dry. Yet the language of the reinstated Civil Law is more colourful than the abrupt and concise language of the Soviet codes which actually resemble a short manual when being read without any comments.

In general, it can be concluded that the core of the Latvian terminology of marriage has remained stable, as entering into marriage is a solid 
procedure where two interested parties give notice to a public or religious institution in order to officially register their relationship. Similarly, both parties often feel the need to terminate this relationship just as officially. This stability of fundamental processes contributes to terminological continuity.

\section{R E F E R E N C E S}

Birziņa, L. 1991. Latviešu juridiskās terminoloǵijas attīstība XIX-XX gs. Rīga: Latvijas Universitāte.

Civillikums. 2013. Law of the Republic of Latvia. Latvijas Vēstnesis.

Civīllikums. 1937. Rīga: Kodifikācijas nodaļa.

Galdia, M. 2009. Legal linguistics. Frankfurt am Main: Peter Lang GmbH.

JTV. 1942. Juridiskās terminoloǵijas vārdnīca. Rīga: Latvju grāmata.

JTV. 1998. Juridisko terminu vārdnīca. Rīga: Nordik.

KPFSR Laul̄̄bas, ǵimenes un aizbildnības likumu kodekss. 1941. Rīga: Sabiedriskiekonomisko rakstu apgādniecība.

Latvijas Padomju Sociālistiskās Republikas Laulības un ǵimenes kodekss. 1969. Rīga: Liesma.

Latvijas Vēstnesis. 1920. Latvijas Vēstnesis, No. 128, 1.

Lazdiņš, J. 2003. Latvijas privāttiesības. Raksti. Rīga: LU žurnāla "Latvijas Vēsture" fonds.

Likums par laulību. 28 February 1921. Likumu un Valdības Rīkojumu Krājums, No. 5 .

Likumu kodekss par civilstāvokḷa aktiem, laulības, ǵimenes un aizbildnības ties̄̄bām. 26 February 1919. Latvijas Sociālistiskās Padomju Valdības Ziņotājs, No. 4.

Mattila, H. E. S. 2013. Comparative legal linguistics: language of law, Latin and modern lingua frances. 2nd ed. Farnham: Ashgate Publishing Ltd.

Štekerhofa, S. 2016. Juridiskās terminoloǵijas attīstība 19. un 20. gadsimtā: nozīmīgākās personības un publikācijas. Terminrade Latvijā senāk un tagad. Rīga: Zinātne, 121-126.

Vucāne, A 2015. Fiktīva laulība cilvēktirdzniecības kontekstā: terminoloǵijas problēmas.Jurista Vārds, Nr. 45 (897), 2015. gada 17. novembrī, 35-38.

1969 Divorce Reform Act. Act of the United Kingdom. Retrieved from http://www. legislation.gov.uk/ukpga/1969/55/pdfs/ukpga_19690055_en.pdf 